UDK: 395.5

Pregledni članak

Primljeno: 12. 10. 2021.

Prihvaćeno za štampu: 12. 11. 2021.

As. Nina Halilbašić

Univerzitet u Bihaću

Islamski pedagoški fakultet

E-mail: nina-balilbasi@@hotmail.com

\title{
SELAM - RIJEČ MIRA
}

\section{Sažetak}

Rad se bavi tematikom vařnosti pozdrava kao početnog socijalnog kontakta, u svrhu stvaranja pozitivne, obostrano ugodne, prijateljske komunikacije, ali i daje kratki osvrt na samu riječ „selam" i njena značenja kroz Kur'an kako bi se iz osnounog izvora islama saznalo šta je istinski mir, kako se on postiže i koja sve značenja podrazumijeva islamski pozdrav.

Na početku se definiše riječ "mir" u bosanskom i arapskom jeziku. Nakon toga se

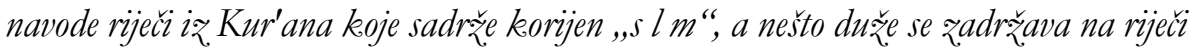
„selam". Rad je jedna vrsta putovanja kroz. kur'anske ajete - zaustavlja se na svakoj riječi „selam", da bi se vidjelo u kojem kontekstu se ona koristi i koju poruku qa nas nosi riznica pronadenih ajeta. Za kratko objašnjenje navedenih ajeta, koristen je tefsir Ibn Kesira. Ponuden je $i$ licni osvrt autora, vlastito raqumijevanje navedenih ajeta $i$ njihovih tumačenja. Śto se tǐce riječi „selam" u hadisima Poslanika, a.s., u radu se navodi nekoliko smjernica na ovu temu iz. Tirmizijeve zbirke hadisa.

Ključne riječi: selam, mir, Kur'an, ajet, hadis.

\section{Uvod}

Čovjek je u svakom vremenu prirodno težio tome da bude u miru sa sobom i s drugima i da ostvaruje uspješne i obostrano prihvatljive socijalne kontakte. Rad tretira islamski pozdrav „selam“ kao početak uspješnog kontakta, ali donosi i njegova šira značenja što se može vidjeti iz definicija riječi ,selam“ navedenih u Rječniku bosanskoga jezika, te u Arapsko-bosanskom rječniku. 
U Rječniku bosanskoga jezika (Halilović S., Palić I., Šehović A., 2010: 654) riječ mir se definiše kao: „Stanje bez rata i ratnih sukoba, bez narušavanja javnog reda, bez svađe diskusija i prepirki, sloga, bez buke i galame, tišina, bez uzbuđenja, spokojstvo, poziv ili upozorenje da se istog trena prestane $s$ bučnim ili agresivnim ponašanjem, tišina, pokoj, počivati u miru Božijem (...)“.

U Arapsko-bosanskom rječniku (Muftić, T., 2017: 772) riječ „selam“ se definiše kao: „Predanost (Bogu), spas, sigurnost, dobrobit, mir, Onaj Koji je slobodan od nesavršenstva ili Koji daje sigurnost (Božije ime), pozdrav, vojna počast, himna, spas, zdravlje, očuvanost, besprijekornost, neoštećenost, cijelost, dobar ishod itd. (...)“.

\section{Riječi u Kur'anu koje sadrže korijen „s I m“}

1. سَلَّمَ selleme, (je) spasio, spas ukazao...

2. سَلَّمْتُمْ sellemtum, (ste) predali, položili, dali...

3. تُسَلِّمُوا

4. يُسَلّْمُوا jusellimuu (da se) pokore, predaju...

5. سَلِّمُوا sellimuu, pozdravite, poselamite...

6. آَسْلَمَ esleme, pokorio se...

7. آََْْمَا eslemaa, (njih dvojica) poslušaše, pokoriše se...

8. آَسْلَمْتُ

9. .

10. آََْلَمْنَا eslemnaa, pokoravamo se...

11. آَسْلَمُوا سنانا eslemuu, (ako se) predaju, pokore...

12. أُسْلِمَ uslime, (da se) predam...

13. تُسْلِمُوَنَ tuslimuune, (da biste se) predali...

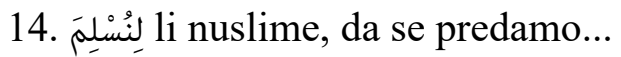

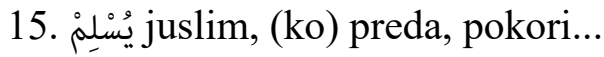

16. يُسْلمُوَنَ juslimuune, (da se) pokore, predaju...

17. آسَلِدِمْ eslim, predaj se, pokori se... 
18. eslimuu, predajte se, pokorite se...

19. آلَسِّلْمِ essilmi, (uđite u) mir, (u) islam...

20. آلسَّلْمِ الَسِمَ esselmi, (budu skloni) miru...

21. آلََّلَمَ esseleme, (ostave na) miru...

22. سَلَََ selemen, potčinjenog, pokornog...

23. سآَمُونَ سكَ saalimuune, zdravi, ispravni...

24. سَلَاهُ selaamun, (pozdrav) mir, spas...

25. سَلَّام سلَّ selaamin, (pozdrav) mir, spas...

26. سَلَكاً سلَا

27. seliimin, zdravim, ispravnim...

28. آَالْنَلَاِْمُ . el islaamu, islam...

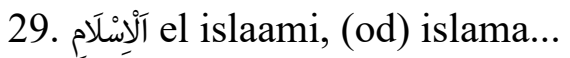

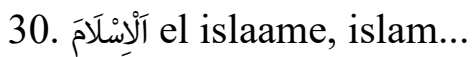

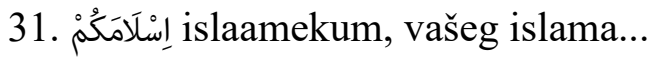

32. إِلَامِهِهْ islaamihim, njihovog islama...

33. مُسْلًِا muslimen, muslimanom, pravim vjernikom...

34. مُسْلِمَيْنِ مُنَّime muslimejni, (nas dvojicu) Tebi odanim, muslimanima...

35. مُسْلمُونَ مُسنِنَ muslimuune, muslimani...

36. مُسْلِمِينَ muslimiine, (od) muslimana...

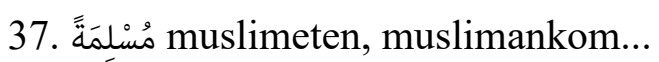

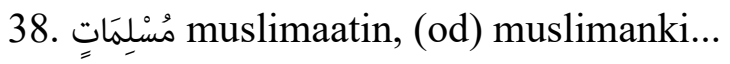

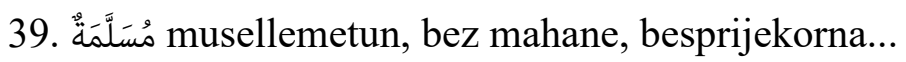

40. Tَسْلِيمًا tesliimen, pokorno...

41. مُسْتَسْلِمُونَ تُسنَ musteslimuune, pokorni, sasvim prepušteni...

42. سُلَّمَ sullemun, ljestve...

43. سُسلَّمَا

(Abdulbaki, M. F., 1982: 355, 356, 357) 


\section{Poseban osvrt na oblik riječi „,selamun/en/in“ kroz kur'anske ajete}

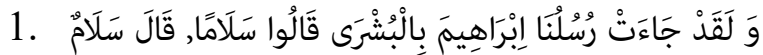

„I Ibrahimu smo izaslanike Naše poslali da mu donesu radosnu vijest. 'Mir!' - rekoše; - 'Mir!' - odgovori on (...)“(Hud, 69).

„Allah Uzvišeni kaže: 'I izaslanici Naši su došli', koji su meleki bili, 'Ibrahimu da mu donesu radosnu vijest', tj. da mu donesu radosnu vijest o Ishaku (...), 'Mir', rekoše, 'Mir', reče on, tj. selamun alejkum - Neka je na vas mir!'“ (Ibn Kesir, 2002: 626)

Ovdje vidimo upotrebu selama kao islamskog pozdrava i uočavamo da ga koriste meleki, kao i vjerovjesnici koji su bili i djelovali prije Muhammeda, a.s. Ovaj jedinstveni pozdrav jedna je od naših poveznica s prijašnjim ummetima muslimana i donosi u naša srca toplinu zajedništva s njima.

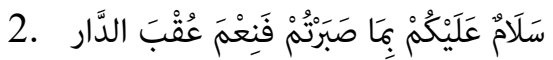

„Mir neka je vama, zato što ste trpjeli, a divno li je najljepše prebivalište!"“ (Er-Ra'd, 24) ,tj. ovuda i onuda za njima će meleki ulaziti čestitajući im ulazak u Džennet. Kada u Džennet budu ušli, za njima će meleki selame uzvikivati čestitajući im ono što im je od Allaha dato, milost, blizinu, boravak na ahiretu u društvu poslanika, vjerovjesnika i iskrenih ljudi. U hadisu stoji da je Allahov poslanik, a.s., posjećivao mezare šehida početkom svake godine, obraćajući se šehidima riječima: 'Selam neka je vama, zato što ste trpjeli, a divno li je najljepše prebivalište'“، (Ibn Kesir, 2002: 669).

Često se čuje kako je strpljenje gorko, a njegovi plodovi slatki. To se proteže i kroz navedeni ajet. Ko se strpi u ime Allaha, dž.š., na svemu što ga zadesi i podnese životne situacije stameno i stabilno, njegova nagrada je selam, mir. Njegova prsa bit će bašča mira, bez obzira na spoljašnje okolnosti. Njegov jastuk bit će mehak, a san rahatan. Potom će svoj mir ponijeti sa sobom i biti jedan od džennetlija.

3. خَالِِينَ فِيهَا بِاذِذِنِ رَبِهِمْ تَحِيَتُهُمْ فِيهَا سَلَام

„,...) i u njima će vječno boraviti, voljom Gospodara njihova, u njima će se riječju 'Mir!' pozdravljati'“، (Ibrahim, 23).

„Kuda god išli i ma gdje se kretali 'u njima će vječno boraviti', neprestano biti i vječno ostati““ (Ibn Kesir, 2002: 683). 
Džennet je stanište ugode, ljepote i nagrade. Takvom staništu priliči najljepši pozdrav - selam.

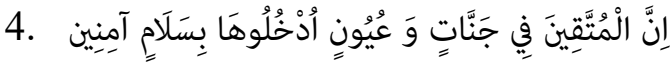

„Oni koji su se Allaha bojali i onog što im je zabranjeno klonili, oni će u džennetskim baščama pored izvora biti. 'Uđite u njih sigurni, straha oslobođeni!'“ (El-Hidžr, 45-46)

Znači ,lišeni svakog straha i zaplašenosti i sigurni od nedaća. Nemojte se plašiti da ćete biti izgnani, ne plašite se prestanka i nestanka“" (Ibn Kesir, 2002: 698).

Dunjalučki život ima svoja pravila i zakone, a jedan od zakona dunjaluka je da na njemu ni tuga i sreća ne traju vječno. Smjenjuju se jedno za drugim, a mogli bismo reći i da dolaze uporedno. Teško je čovjeku zamisliti da će dobiti džennetske blagodati kojima nema kraja, jer smo navikli da sve što traje, mora se i prekinuti. Allah zna naše najdublje strahove i razmišljanja pa nas tješi i ohrabruje. Naš zadatak je da budemo bogobojazni, svjesni Allaha, dž.š., da ulažemo trud u ostavljanju grijeha, a Allah nam daje mir koji neće prestati, niti će imati rok trajanja. Gdje se naseli selam (mir) on odatle otjera uznemirenost $\mathrm{i}$ strah.

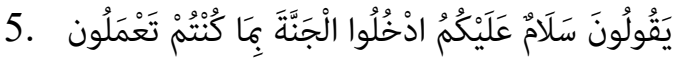

„(...) i kojima će govoriti: 'Mir vama! Uđite u Džennet zbog onoga što ste činili!'‘ (En-Nahl, 32)

„Zatim je Uzvišeni obavijestio o stanju vjernika prilikom smrti, pa kaže da su oni dobri, tj. oslobođeni i čisti od širka, prljavštine i svakog zla, njih će meleki pozdravljati i obradovati Džennetom (...)“ (Ibn Kesir, 2002: 713).

Svjesni smo da su naša djela neznatna, ma koliko ih bilo, i ma kakva bila. Allah će robove uvesti u Džennet iz Svoje velike milosti i dobrote. Ipak, u ajetu vidimo da su djela itekako važna. Svaki minut i svaki sat pravimo izbore i nije svejedno da li ćemo izabrati da uradimo loše djelo ili dobro djelo. Ko se odluči za dobro, približio se Allahovoj milosti, koja vodi u Džennet.

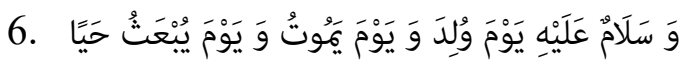


„I neka je mir njemu na dan kada se rodio i na dan kada je umro i na dan kad bude iz mrtvih ustao!"“ (Merjem, 15)

To jest „bit će siguran u ova tri staništa. Sufjan b. Ujejne kaže: 'Najusamljenije se čovjek osjeća na tri mjesta, a kroz koja prolazi: kada se rađa i kada čovjek spozna odakle je izašao, kada umire i kada čovjek ugleda nepoznate ljude i na Dan proživljenja, kada se čovjek nađe u ogromnom mnoštvu. Allah, dž.š., je na ovim staništima počastio posebnom sigurnošću Jahjaa, sina Zekerijjaovog, a.s. (...)“ (Ibn Kesir, 2002: 801).

Čovjek je društveno biće. Ljudi iz našeg života su nam potrebni, međutim, nemojmo zaboraviti da se rađamo sami, umiremo sami, i bit ćemo proživljeni sa svojim djelima. Sami ćemo odgovarati za njih pa molimo Allaha, dž.š., da nas učvrsti u času preseljenja i na Danu polaganja računa, da tada budemo u selamu, sigurni i spašeni, kao što je siguran i spašen Jahja, a.s.

\section{7. وَ السَّلَامُ عَلَيَّ يَوْمَ وُلِذْتُ وَ يَوْمَ امَوْتُ وَ يَوْمَ أبنْعَثُ حَيَّا}

„I neka je mir nada mnom na dan kada sam se rodio i na dan kada budem umro i na dan kada budem iz mrtvih ustajao!“” (Merjem, 33)

„Na prvom mjestu ističe svoje robovanje Allahu, dž.š., jer je stvorenje kao i ostala stvorenja koja žive i umiru i koja će biti proživljena kao i ostala stvorenja, neka mu je najljepši blagoslov od Allaha, dž.š., i najčišći pozdrav“ (Ibn Kesir, 2002: 803-804).

Ovdje možemo primijetiti isti ajet kao prethodni, samo u prvom licu umjesto u trećem. Allahov poslanik, Isa, a.s., također je tražio selam (mir) od Uzvišenog Allaha, i kako se naglašava u tefsiru, time istakao i to da je potreban Božijeg mira i spasa koji samo On daje.

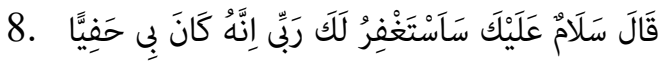

„'Mir tebi!' - reče Ibrahim. 'Molit ću Gospodara svoga da ti oprosti, jer On je vrlo dobar prema meni.'“‘ (Merjem, 47)

„Značenje Ibrahimovih riječi upućenih ocu: 'Mir tebi!', jeste: Što se mene tiče, s moje strane ti se zbog očinskog hurmeta neće ništa loše desiti i ja ću moliti Gospodara svoga da ti oprosti, tj. molit ću Ga da te uputi i da ti grijehe oprosti, jer je On vrlo dobar prema meni““(Ibn Kesir, 2002: 806). 
Otac pokušava odvratiti Ibrahima, a.s., od robovanja Allahu, dž.š., te mu upućuje riječi koje ne izazivaju ugodu. Ipak, Ibrahim, a.s., njemu želi mir (selam) i obećava da će moliti da mu se oprosti. Ovaj kur'anski ajet pun je pouka za nas, kao nar košpica. Možemo uočiti da čovjek koji nosi mir u svojim prsima ne koristi uznemirujuće riječi. Ne vrijeđa. A kada ga uvrijede, on se i dalje obraća mirno, jer on daje ono što ima.

U tefsiru ovog ajeta vidimo da Ibrahim, a.s., obećava ocu kako ga ništa ružno neće zadesiti $\mathrm{s}$ njegove strane. Zar nije to cilj islamskog pozdrava? Bilo bi veoma dobro da sebi osvijestimo selam, pa idući put kad nekoga poselamimo, da u sebi podrazumijevamo da mu obećavamo time selam (mir), a to znači da smo odlučili da ta osoba neće od nas osjetiti neugodnosti. Nećemo je uznemiriti svojim jezikom, ni rukom, niti ćemo je ogovarati, napasti, udariti, pokrasti i slično.

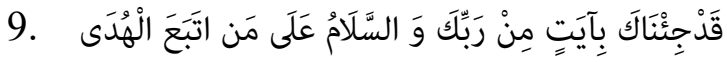

„Donijeli smo ti dokaz od Gospodara tvoga, a nek živi u miru onaj koji Pravi put slijedi.“( (Ta-Ha, 47)

„tj. mi smo ti donijeli čudo od Gospodara tvoga, pa živi u miru ako budeš slijedio uputu“ (Ibn Kesir, 2002: 823).

Kad bismo bili upitani koja je najveća blagodat u životu koju imamo, da li bismo se sjetili upute? A ona je najveći poklon od Allaha, dž.š., koji bismo mogli staviti na prvo mjesto, ispred zdravlja i svega drugog. Svaki dan molimo Allaha, dž.š., kroz svoje namaze da nas uputi na pravi put, jer stranputica je mnogo i svakodnevno nas zovu da njima pođemo. Ko bude ulagao trud da bude na uputi, on je već u selamu, živi u miru, bez obzira na (ne)povoljnost okolnosti, a poselamljen će biti i u Džennetu.

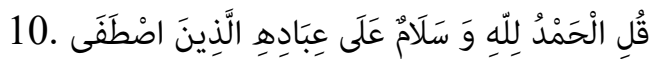

„Reci: 'Hvala Allahu i mir robovima Njegovim koje je On odabrao!'“ (En-Neml, 59)

„Uzvišeni Allah naređuje Svom Poslaniku, a.s., da kaže: 'Hvala Allahu', tj. na Njegovim blagodatima koje je dao Svojim robovima, toliko da, kada bi ih brojali, ne mogu ih nikada nabrojati, i na uzvišenim svojstvima i lijepim imenima Njegovim kojima je On opisan. Zatim mu naređuje da donosi mir i blagoslov na one Njegove robove koje je On 
odabrao i izabrao, a to su plemeniti poslanici, neka je na njih najvredniji salavat i selam“ (Ibn Kesir, 2002: 980).

\section{1. سَلَاٌْ عَلَيْكُمْ لَا نَبْتَغِى الْجَاهِلِين}

„Mir vama! Mi ne želimo društvo neukih“ (El-Kasas, 55).

„tj. kada im pristupi neki bezobziran neznalica i govori im o nečemu na što njima ne dolikuje odgovoriti, oni se okrenu od njega i ne uzvraćaju mu ružnim govorom poput njegovog, i od njih se čuje samo lijep govor““ (Ibn Kesir, 2002: 1000).

Zamislimo čovjeka kao narandžu, a iskušenje ili konfliktnu situaciju kao stisak. Ako pritisnemo narandžu, iz nje će izaći sok od narandže, jer je to jedino što se u njoj nalazi. Također, ako čovjeka pritisne iskušenje, iz njega će izaći ono što je u njegovoj nutrini. Kako smo već spominjali, onaj ko je u miru, ne donosi nemir drugima, bez obzira kako oni pristupali njemu. U njemu je mir i on ga širi oko sebe, a gdje se osjeti uznemireno, odatle se blago distancira, čuvajući sopstveni mir.

12. تَحِيَتُهُمْ يَوْمَ يَلْقَوْنَهُ سَلَامُ وَ أَعَدَّ لَهُهْ اَجْرَا كَرِيمًا

„A na dan kad oni pred Njega stanu, On će ih pozdravljati sa: 'Mir vama!' - i On im je pripremio nagradu plemenitu“"(El-Ahzab, 44).

„Čini se - a Allah najbolje zna - da se želi reći da će im pozdrav od Uzvišenog Allaha, na Dan kada Ga sretnu, biti selam, tj. na Dan kada ih pozdravi (...)“(Ibn Kesir, 2002: 1075).

13. سَلَامُ قَوْلَا مِن رَبِّ رَّحِيم

„'Mir vama!' - bit će riječi Gospodara Milostivog“ (Ja-Sin, 58).

„Ibn Abbas o riječima Uzvišenog: 'Selam vama - bit će riječi Gospodara Milostivog' veli: 'Sam Uzvišeni Allah je Selam žiteljima Dženneta', a veli se da će ih On, neka je Uzvišen, pozdraviti selamom“" (Ibn Kesir, 2002: 1120).

Allah je Selam i od Njega je selam, kako je kazala naša majka Hatidža, r.a. S obzirom na to da nemamo svoje snage da nešto postignemo od dobra, niti da izbjegnemo od zla, tražimo selam (mir) na nNjegovom Izvoru. 


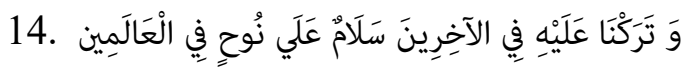

„I u naraštajima kasnijim mu spomen sačuvali: 'Mir Nuhu od svjetova svih!"“ (Es-Saffat, 78-79)

„I riječi Uzvišenog: 'Selam Nuhu među narodima!' pojašnjavaju kako je ovjekovječio njemu lijep spomen i lijepu pohvalu, te njega selame sve skupine i narodi. 'Eto tako Mi nagrađujemo one koji dobra djela čine.'“" (Ibn Kesir, 2002: 1131)

Čovjek na ovome svijetu teži da ostavi iza sebe dobar i lijep trag, da ga drugi spominju po dobru kad preseli na ahiret. Allah nam išareti u ovom ajetu koji je način da to i postignemo. Navodi to kao posljedicu, kao nagradu onima koji čine dobra djela. I zaista, svjedoci smo da su živi dobročinitelji, vakifi, alimi... Sjećanja na njih ne blijede, a njihovi tragovi su zauvijek ostali na mjestima gdje su djelovali. Življi su od mnogih koji se ubrajaju u žive i njihova zaostavština i dalje o njima govori, a dobra djela im ne prestaju stizati.

15.

„I u naraštajima kasnijim mu spomen sačuvasmo: 'Neka je u miru Ibrahim!'“ (Es-Saffat, 108-109)

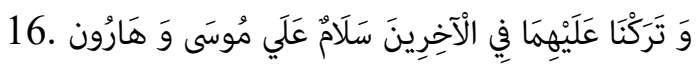

„I u naraštajima kasnijim im spomen sačuvali: 'Neka su u miru Musa i Harun!'““ (Es-Saffat, 119-120)

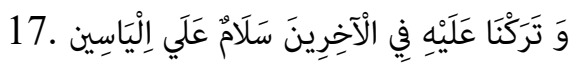

„I sačuvasmo mu spomen u naraštajima kasnijim: 'Nek je u miru Ilijas!'““ (Es-Saffat, 129-130)

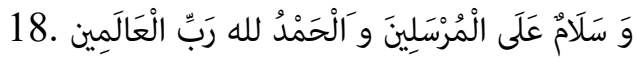

„I mir poslanicima i hvaljen neka je Allah, Gospodar svjetova!“ (EsSaffat, 181-182)

„Prenosi Taberani od Zejda ibn el-Erkama, a on od Allahovog poslanika, a.s., da je rekao: 'Ko poslije svakog namaza prouči tri puta: ' Slavljen i Čist je Gospodar tvoj, Gospodar dostojanstva, i visoko je iznad onoga što Mu pripisuju oni! I selam neka je na poslanike, a hvala Allahu, svjetova Gospodaru!', zahvatio je najveću mjeru nagrade“ (Ibn Kesir, 2002: 1139). 
Allah, dž.š., je slao poslanike da narodu budu zvijezde vodilje, da opominju i donose radosne vijesti. Svi oni su u miru Božijem. Mir su širili i živjeli. Pa ko hoće da bude u miru, neka pogleda u njihove živote. Tu će naći uputstvo i model ponašanja koji dovodi do mira na oba svijeta. Kad čitamo o njima, iznenađuje nas broj i jačina iskušenja koja su prolazili, ali putem njih vidimo i to da čovjek i u iskušenjima može biti miran i dostojanstven, dok su mnogi ljudi i u blagodatima nemirni.

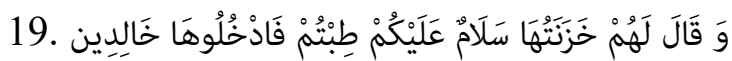

„ČCuvari njegovi će im reći: 'Mir vama, od grijeha ste čisti, zato uđite u nj, u njemu ćete vječno boraviti!'“ (Ez-Zumer, 73)

„Meleki će ih uz počast i poštovanje dočekati, da ih poselame, obraduju i pohvale. Kada dožive sve ove počasti bit će sretni i veseli, sukladno svakom užitku koji će doživjeti““(Ibn Kesir, 2002: 1169).

„I riječi Uzvišenog: 'tj. vaša su djela i riječi lijepe, vaši su napori bili dobri i vaša je nagrada dobra.'“" (Ibn Kesir, 2002: 1170).

20. فَاضْفَحْ عَنْهُمْ وَ قُلْ سَلَامُ فَسَوْفَ يَعْلَمُوُن

„Ti se oprosti od njih i reci: 'Ostajte u miru!' - ta sigurno će oni zapamtiti“" (Ez-Zuhruf, 89).

„Ti, dakle, nemoj im odgovarati na riječi kojima oni tebe provociraju. Ne uzvraćaj ružnim. Nego, pak, pokušaj ih pridobiti i odvoji se od njih djelom i riječju (...) (“) (Ibn Kesir, 2002: 1227).

21. أذخْلُوهَا بِسَلَامِ ذِلِكَ يَوْمُ الْخُلُود

„Uđite u nj, u miru, ovo je Dan vječni!““ (Qaf, 34)

„Uđite u njega, misli se u Džennet, sa selamom, spašeni, tj. spašeni od džehennemske kazne, a i meleki ih dočekuju selamom. Ovo je dan vječnosti, tj. vječno će boraviti u Džennetu, neće nikada umirati, niti iseliti se, a ni poželjeti nešto drugo“ (Ibn Kesir, 2002: 1292).

Kako smo spominjali u prethodnom dijelu teksta, kad nekoga poselamimo, dajemo mu garanciju da je od nas miran i da neće biti bihuzuren. A kada selam razumijemo i kao spas, to bi značilo da onoga koga selamimo (za njega) dovimo i želimo da bude spašen u vječnosti, da uspješno položi svoj ahiretski ispit i bude sačuvan od Džehennema, 
a uveden u džennetske bašče. Zar postoji preča i važnija dova koju možemo uputiti jedni za druge?

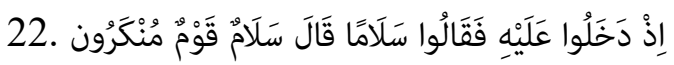

„Kada mu oni uđoše i rekoše: 'Mir vama!', i on reče: 'Mir vama, ljudi neznani!'“ (Ez-Zarijat, 25)

„Pozdrav koji je izgovorio Ibrahim, a.s., bio je u nominativu - u odnosu na selam gostiju koji je bio u akuzativu - jači je i bolji, kao što kaže Uzvišeni: 'Kada pozdravom pozdravljeni budete, ljepšim od njega otpozdravite, ili ga uzvratite.'““ (4: 86) (Ibn Kesir, 2002: 1297)

Iz ajeta vidimo da Ibrahim, a.s., još uvijek ne zna ko su gosti, a upućuje im selam. Time nas je podučio da nazivamo selam znanima i neznanima. Neka od nas bude svako miran.

فَسَلَامُ لَكَكَ مِنْ اَصْحَابِ الْيَمِين

„Pa, pozdrav tebi od onih koji su sretni!““ (El-Vakia, 91)

„El-Buhari kaže da 'selamun leke' znači: Zagarantovano ti je da ćeš biti od onih s desne strane“ (Ibn Kesir, 2002: 1338).

Oni koji biraju desnu stranu, stranu dobra, još na ovom svijetu su mirni, mirne nutrine i mirne savjesti. Mirni sa svojim izborima. U mirnoj savjesti stanuje sreća.

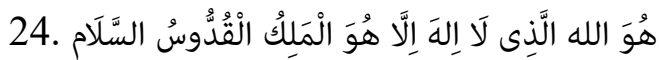

„On je Allah - nema drugog boga osim Njega, Vladar, Sveti, Onaj Koji je bez nedostatka (...)“ (El-Hašr, 23).

„Onaj Koji je bez nedostatka, tj. bez ikakve mahane. On je savršen u Svojoj biti, atributima i djelima“" (Ibn Kesir, 2002: 1367).

Es-Selam je jedno od Allahovih imena. On je mir i spas, čist od svakog nedostatka i mahane. Savršen. Ljudska priroda teži savršenstvu. Teži ljepoti, vanjskoj i unutrašnjoj. Odakle potiče ta potreba? Da li je to samo težnja ka Stvoritelju, koji je upravo to, sama ljepota i savršenstvo.

25. سَلَاٌٌْ هِيَى حَتَى مَطْلَعَع الْفَجْر

„Sigurnost je u njoj sve dok zora ne svane“ (El-Kadr, 5).

„tj. noć Kadr je sigurna. U njoj šejtan ne može činiti zlo, ni navoditi na njega“" (Ibn Kesir, 2002: 1515). 
Kada smo bez zaštite i sigurnosti, lahka smo meta svemu onome što je loše. A gdje potražiti sigurnost i spas nego kod Allaha, dž.š. Bez Njegove pomoći i podrške se ne možemo spasiti zla, izbjeći grijeh, niti možemo učiniti bilo koje dobro, ako nam On ne pomogne. Nemamo snage da izbjegnemo grijeh, niti moći da uradimo dobro, osim $\mathrm{s}$ Allahom.

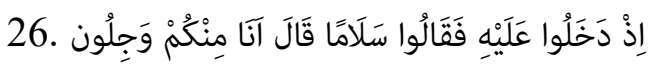

„Kada su mu ušli i rekli: 'Mir!' - on je rekao: 'Mi smo se vas uplašili.'“ (El-Hidžr, 52)

„tj. prepali smo se, te spominje razlog njegovog straha od njih“ (Ibn Kesir, 2002: 699).

„'Ne plaši se, rekoše', tj. nema razloga za strah, donosimo ti radosnu vijest (...)““ (Ibn Kesir, 2002: 699).

Onaj ko dolazi sa selamom, donosi sigurnost i radosne vijesti, a ne donosi strah i nevolju. Imajmo to na umu kad nazivamo selam pri dolasku u društvo drugih ljudi.

27. لَا يَسْمَعُونَ فِيهَا لَغْوًا الِلَّا سَلَامًا

„U njima prazne besjede neće slušati, već samo: 'Mir!'“ (Merjem, 62)

„tj. u tim džennetima neće biti razgovora koji nema smisla, već će se govoriti: 'Mir!'“ (Ibn Kesir, 2002: 810)

Govor je veliki dar od Allaha, dž.š., ljudima. On je kao nož kojim možemo nekoga porezati, ali i izrezati hranu i počastiti ga. Kako ćemo ga koristiti, dato nam je na izbor. Na jednoj strani su riječi mira, kojima mirimo ljude i činimo da se lijepo osjećaju u našem društvu. Na drugoj strani su prazne besjede, razgovori bez smisla, ogovaranje koje kao zarazna bolest zahvata srca ljudi, prenošenje riječi s ciljem zavađanja, ismijavanje. Za koji govor smo se opredijelili? Onaj ko izabere ono što je bolje, izabrao je dio Dženneta na zemlji.

قُقُنًَا يَا نَارُ كُونِنَ بَرْدًا وَ سَلَامًا عَلَى إِبْرَاهِيم .

„'O vatro' - rekosmo mi - 'Postani hladna, i spas Ibrahimu!'، (ElEnbija', 69)

„Ibn Abbas kaže: 'Da Allah nije rekao: 'I spas', Ibrahim bi stradao od njene hladnoće.'“ (Ibn Kesir, 2002: 849) 
Ibrahim, a.s., je bačen u vatru s ciljem da ga ljudi kazne. Izvana to izgleda kao muka i iskušenje. Vidimo u svom okruženju mnoge ljude koji gore u vatri iskušenja i problema. Međutim, poznato je da vanjština i suština počesto nisu iste. Naše oči su svjedok nepouzdan. Ako Allah hoće, može i vatru hladnom učiniti, i kome hoće, može iskušenje i problem prijatnim učiniti. Zar ne vidjesmo takve, i pored mnogih problema za koje znamo da ih imaju, nasmijane.

29. وَ إذَا خَاطَبَهُمُ الْجَاهِلُونَ قَالُوا سَلَامًا

„(...) a kada ih bestidnici oslove, odgovaraju: 'Mir vama!'“ (El-Furkan, 63)

„tj. ako ih neznalice i bezobraznici oslove ružnim riječima, ne odvraćaju im istim načinom, nego praštaju, okrenu se od njih i ostave ih i govore samo dobro (...)“(Ibn Kesir, 2002: 947).

30. وَ يَلْقَنْنَ فِيَها تَحِيَّتًا وَ سَلَامًا

„(...) i u njima će pozdravom i blagoslovom biti susretani““ (El-Furkan, 75).

„tj. bit će presretani i prvi pozdravljani i čašćeni, pa će biti blagoslovljeni i spašeni (...)“( (Ibn Kesir, 2002: 950).

Vjernici će biti presretani sa selamom kao što su oni druge sa selamom presretali, žurili da drugima požele dobro i mir. Zar ćemo biti nagrađeni ili kažnjeni osim onim što smo sami radili?

\section{1. لَا يَسْمَعُونَ فِيهَا لَغْوًا وَ لَا تَأْثِيمًا إِلَّ قِيلًا سَلَامًا سَلَالًَا}

„U njima neće slušati prazne besjede ni govor grešni, nego samo riječi: 'Mir, mir!'“ (Kur'an, El-Vakia, 25-26)

„U Džennetu neće čuti prazan i beznačajan govor, ni riječi koje sadrže slabo i bezvrijedno značenje. Kao što kaže Uzvišeni: 'U kome prazne besjede neće slušati' (88: 11), tj. prazne priče, 'ni govor grešni', tj. ni govor koji u sebi sadrži nešto ružno. 'Nego samo riječi: Selam, selam!', tj. ništa drugo do samo pozdravljanje jedan drugoga, kao što kaže Uzvišeni: 'U njima će se riječju selam pozdravljati, (14: 23) i (10: 10), a njihov govor bit će također čist od pokvarenosti i griješenja“" (Ibn Kesir, 2002: 1330). 


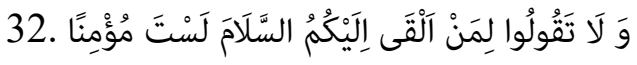

„(...) i onome ko vam nazove selam ne recite: 'Ti nisi vjernik!'“ (Kur'an, En-Nisa, 94)

„El-Buhari prenosi od Ibn Abbasa da je u vezi s navedenim riječima rekao: 'Jedan je čovjek uzimao svoj plijen, pa ga je našla grupa muslimana, a on im je rekao: 'Es-selamu alejkum!' - 'Mir na vas!' Potom su ga ubili i uzeli njegov plijen, pa je Allah objavio: '(...) i onome ko vam nazove selam, nemojte reći: 'Ti nisi vjernik!' Potom Ibn Abbas kaže: 'Taj plijen je ovosvjetska prolazna dobrobit!' '(...) jer kod Allaha su mnoga dobra!' 'Dakle, kod Njega je bolja dobit od dunjalučke, koju vi želite i što vas je navelo da ubijete ovog čovjeka koji vam je nazvao selam i izjavio da vjeruje. Vi ste to zanemarili i optužili ga za pretvaranje i skrivanje nevjerstva, kako biste uzeli od njega to što ste uzeli. Međutim, halal opskrba koja je kod Allaha za vas je bolja od te koju ste uzeli."“ (Ibn Kesir, 2002: 302)

Hrabro je (ili ludo) procjenjivati stanje nečijeg srca, a danas vrlo lahko dajemo sebi dozvolu za to. Ni sami nismo sigurni do samog kraja šta će biti s nama. Nada u dobar završetak postoji, ali ne i garancija.

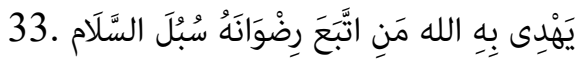

„(..) kojom Allah upućuje na puteve spasa one koji nastoje steći zadovoljstvo Njegovo" (El-Maide, 16).

„tj. puteve izbavljenja i sigurnosti““(Ibn Kesir, 2002: 355).

Zanimljivo je primijetiti da se riječ 'put' spominje u množini. Da li je samo naš put i način na koji razumijemo život ispravan?

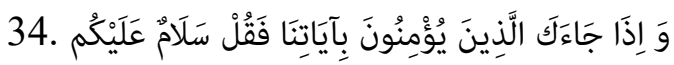

„A kada ti dođu oni koji u riječi Naše vjeruju, ti reci: 'Mir vama!'““ (ElEnam, 54)

„tj. počasti ih uzvraćanjem selama $i$ obraduj ih velikom i sveobuhvatnom Allahovom milošću prema njima“" (Ibn Kesir, 2002: 413).

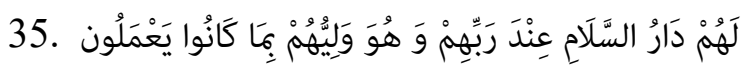

„Njih čeka Kuća blagostanja u Gospodara njihova; On će biti zaštitnik njihov zbog onoga što su činili““ (El-Enam, 127). 
„Allah, dž.š., opisuje Džennet kućom (selama) mira i selameta (bez nedostatka) zbog toga što su njegovi stanovnici još prije ispravno slijedili pravi put i ugledali se na poslanike i njihov način života. Pa, kao što su ostali spašeni (salimi), od stranputice, isto tako će ući u Kuću selama (spasa)“ (Ibn Kesir, 2002: 436).

36.

„,...) i oni će stanovnicima Dženneta viknuti: 'Mir vama!'“ (El-A'raf, 46)

„Kad ugledaju džennetlije, nazvat će im selam. Ali, oni do tada još neće ući u Džennet, iako će to željeti““ (Ibn Kesir, 2002: 464).

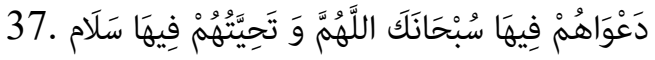

„Molitva njihova bit će u njima: 'Hvaljen neka si, Allahu!', pozdrav njihov: 'Mir vama!'“‘ (Junus, 10)

„Riječi Uzvišenog: 'Pozdrav njihov: Selam!', jesu kao riječi Uzvišenog: 'A na dan kad oni pred Njega stanu, On će ih pozdraviti sa: Mir vama!'‘(33: 44) (Ibn Kesir, 2002: 589)

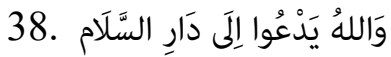

„Allah poziva u Kuću mira...“ (Junus, 25)

„U hadisu koji prenosi El-Lejs od Džabira bin Abdullaha, r.a., stoji da je rekao: /554/ 'Izašao nam je Allahov poslanik, a.s., jednog dana, zatim je rekao: 'Vidio sam u snu kao da je Džibril kod moje glave, a Mikail kod mojih nogu, pa je jedan od njih dvojice govorio svome drugu: 'Navest ću primjer: 'Slušaj, čule ti uši, i poimaj, srce ti poimalo! Primjer tvoj i tvoga naroda jeste kao primjer vladara koji je uzeo predio, zatim sagradio u njemu kuću i priredio u njoj gozbu, zatim poslao izaslanika da pozove ljude na ručak, pa su se neki odazvali, a neki nisu. Allah je Vladar, predio je Islam, kuća je Džennet, a ti, o Muhammede, poslanik si; ko ti se odazove ući će u islam, a ko uđe u islam ući će u Džennet, a ko uđe u Džennet jest će iz njega'“‘ (Ibn Kesir, 2002: 594).

39. قِيَل يَا نُوحُ اهْبِطْ بِسَلَامِ مِنَّا وَ بَرَكَاتٍ عَلَيْنك

,'O Nuhu' - bi rečeno - 'iskrcaj se, s pozdravom Našim i blagoslovima tebi (...) $)^{\prime c 6}(\mathrm{Hud}, 48)$. 
„Allah Uzvišeni iznosi šta je Nuhu, a.s., rečeno kada je njegova lađa pristala na planini Džudijj - tj. mir i blagoslov na njega, one koji su s njim, i na sve vjernike do Sudnjeg dana. Muhammed ibn Ka'b kaže da se ovaj mir i blagoslov odnosi na svakog vjernika i vjernicu do Sudnjeg dana“ (Ibn Kesir, 2002: 623).

\section{Nekoliko hadisa o vrijednosti i propisima nazivanja selama}

(Hadisi uzeti iz hadiske zbirke Džami'-sunen, imama Tirmizija. Poglavlje o traženju dozvole i lijepom ponašanju)

\section{O širenju selama}

Ebu Hurejre prenosi da je Poslanik, a.s., rekao: „,Tako mi Onoga u Čijoj je ruci moj život, nećete ući u Džennet sve dok ne budete (istinski) vjerovali, a nećete (istinski) vjerovati sve dok se međusobno ne budete voljeli! Hoćete li da vas uputim na nešto zbog čega ćete se, ako ga budete činili, međusobno voljeti? Širite selam među sobom!“" (Hasensahih) (Et-Tirmizi, M., 2010: 459)

\section{O dostavljanju selama}

Prenosi se od Ebu Seleme da je Poslanik, a.s., jednom prilikom rekao Aiši: „Džibril ti naziva selam!“ Ona reče: „Neka je i s njim mir i Allahova milost i bereket!“

U fusnoti navedenog hadisa nalazimo dodatno pojašnjenje: „En-Nevevi smatra da je ovaj hadis dokaz da se selam može poslati po drugoj osobi i da ga je ova dužna prenijeti. Kada se određenoj osobi prenese selam, ona je dužna istog momenta na taj selam odgovoriti. En-Nesai u Sunenu bilježi da je neki čovjek iz plemena Benu Temim Vjerovjesniku, s.a.v.s., prenio selam od svoga oca, a Vjerovjesnik, s.a.v.s., čuvši to, reče: 'Neka je mir i s tobom i s tvojim ocem!'“" (Hasen-sahih) (EtTirmizi, M., 2010: 464, fusnota 1513)

\section{O vrijednosti onoga koji prvi naziva selam}

Ebu Umame je kazao: „Neko upita Allahovog poslanika, s.a.v.s.: 'Allahov poslaniče, kada se dvije osobe susretnu, koja će prva nazvati selam?' 'Ona koja više teži Allahovoj milosti.' - odgovori on“ (Hasen) (Et-Tirmizi, M., 2010: 465). 


\section{O nazivanju selama djeci}

Prenosi se od Sejjara da je rekao: „Putovao sam sa Sabitom elBunanijem koji je, prošavši pored djece, nazvao selam. Sabit je rekao: 'Putovao sam sa Enesom koji je, prošavši pored djece, nazvao selam. Enes je rekao: 'Putovao sam s Vjerovjesnikom, s.a.v.s., koji je, prošavši pored djece, nazvao selam'“‘ (Et-Tirmizi, M., 2010: 466).

U fusnoti ovoga hadisa stoji: „En-Nesai u Sunenu bilježi preko Džabira b. Sulejmana, da je Sabit el-Bunani kazao: 'Allahov poslanik, s.a.v.s., bi posjetio Ensarije, nazvao selam njihovoj djeci, pomilovao ih po glavi i upućivao Allahu za njih dovu'“ (Sahih) (Et-Tirmizi, M., 2010: 466, fusnota 1520).

\section{O nazivanju selama pri ulasku u kuću}

Enes, r.a., prenosi: „Allahov poslanik, s.a.v.s., mi jednom prilikom reče: 'Sinko, kada uđeš kod svoje čeljadi, nazovi selam. Taj će selam biti bereket i za tebe i za tvoju kućnu čeljad'“ (Hasen-sahih-garib) (EtTirmizi, M., 2010:468).

\section{O nazivanju selama prije bilo kakvog razgovora}

Prenosi se od Džebira b. Abdullaha da je Allahov poslanik, s.a.v.s., rekao: „Selam se naziva prije (bilo kakvog) razgovora“ (Munker) (EtTirmizi, M., 2010: 469).

\section{Konjanik naziva selam pješaku}

Prenosi se od Fedale b. Ubejda da je Vjerovjesnik, s.a.v.s., kazao: „Konjanik će nazvati selam pješaku, pješak stajaču, dok će manja skupina nazvati selam većoj skupini““ (Hasen-sahih) (Et-Tirmizi, M., 2010: 472).

Bit ćemo slobodni u poređenju konjanika s osobama koje upravljaju prijevoznim sredstvima u današnjem vremenu.

\section{O nazivanju selama pri dolasku i odlasku}

Ebu Hurejre prenosi da je Allahov Poslanik, s.a.v.s., rekao: „Kada neko od vas dođe među ljude, neka nazove selam i, ako hoće sjesti, neka sjedne. Potom, kada bude odlazio, neka (ponovo) nazove selam, jer prvi selam nimalo nije preči od posljednjeg“" (Hasen) (Et-Tirmizi, M., 2010: 473). 


\section{O nazivanju selama prije traženja dozvole za ulazak}

„Prenosi se od Amra b. Abdullaha b. Safvana da je Safvan b. Umejje poslao Kaledea Hanbela da odnese mlijeka, sijere (gruše) i sitnih krastavaca Vjerovjesniku, s.a.v.s., koji se nalazio iznad doline (Mekke). 'Ušao sam kod njega' - veli Kalede - 'ne tražeći dozvolu i ne nazvavši selam'. (Ugledavši me), Vjerovjesnik, s.a.v.s., reče: 'Vrati se i reci: 'Esselamu alejkum, mogu li ući?'“ (Hasen-garib) (Et-Tirmizi, M., 2010: 477)

\section{O načinu nazivanja selama kada neko spava}

Prenosi se da je Mikdad b. Esved kazao: „Jedne prilike smo se moja dva druga i ja primicali ashabima, a bili smo gotovo ogluhli i obnevidjeli od gladi i umora ne bi li nam dali hrane. Niko nas od njih ne primi (jer je ni za sebe nisu imali). Mi tada odosmo Vjerovjesniku, s.a.v.s. On nas uze i odvede kući. Pošto je imao tri koze, Vjerovjesnik, s.a.v.s., reče: 'Pomuzite ih i popijte mlijeka.' Mi ih pomuzosmo i svako popi svoj dio mlijeka. Allahovom Poslaniku, s.a.v.s., ostavismo njegov dio. Allahov Poslanik, s.a.v.s., dođe noću, nazva selam poluglasno, kako se spavač ne bi probudio, i čuo ga onaj ko je budan, ode do džamije, klanja, a potom uze svoj dio i popi““ (Hasen-sahih) (Et-Tirmizi, M., 2010: 483).

\section{Zaključci}

Riječ selam u većini slučajeva prepoznaje se kao islamski pozdrav pri početku socijalnog kontakta u svrhu pozitivne i obostrano prihvaćujuće atmosfere, dok se kroz rad moglo uvidjeti da taj termin ima mnogo širi kontekst i značenje, pa se kroz kur'anske ajete prepoznaje još kao mir, sigurnost, spas, ispravnost, pokoravanje i slično.

Selam, kao pozdrav, koristi Allah, dž.š., upućujući ga vjernicima koji slijede Pravi put. Koristili su ga poslanici i vjerovjesnici u prijašnjim ummetima, kao što ga koriste i muslimani iz ummeta Muhammeda, s.a.v.s.

Osoba koja naziva selam izbjegavat će da to bude rečeno formalno ili neprijatnim tonom. Nazvanim selamom drugoj osobi treba iskreno željeti mir, garantujući sigurnost i bezbjednost od svog jezika i ruku.

Selam ima značenje dove za onoga kome se upućuje, da živi u miru i da se spasi na oba svijeta. 
Selam se naziva i prilikom susreta, kao i pri rastanku.

Najbolji odgovor na uvrede i neadekvatno ponašanje je uzvraćanje selamom i dobrotom te blaga distanca ako za tim postoji potreba.

Međusobno nazivanje selama utiče na zbližavanje srca muslimana, što dalje vodi ka jačanju imana, a u konačnici vodi u Džennet.

\section{Literatura:}

Korkut, B., (1992) Kur'an s prevodom. Medina: Kompleks Hadimulharemejniš-šerifejni - Melik Fahd.

Abdulbaki, M. F. (1982) El Mu'džemul mufehres li elfazil Kur'anil Kerim. Istanbul: El mektebetul islamijje Muhamed Ozdemir.

Ibn Kesir, (2002) Tefsir Ibn-Kesir, skraćena verzija. Sarajevo: Visoki Saudijski komitet za pomoć BiH.

Halilović, S., Palić, I., Šehović, A. (2010) Rječnik bosanskoga jezika. Sarajevo: Filozofski fakutet u Sarajevu.

Muftić, T. (2017) Arapsko-bosanski rječnik. Četvrto izdanje. Sarajevo: ElKalem.

Et-Tirmizi, M. (2010) Tirmizijin Džami'-sunen (Tirmizijina zbirka hadisa sa komentarom prof. Mahmuta Karalića): O traženju dozvole i lijepom ponašanju. Novi Pazar: El-Kelimeh i Fakultet za islamske studije. 
Nina Halilbašić, BA

University of Bihac

Islamic Pedagogical Faculty

E-mail:nina-balilbasi@hotmail.com

\section{SALAM - THE WORD OF PEACE}

\section{ABSTRACT}

This paper deals with the importance of greeting as an initial social contact, in order to create positive, mutually pleasing, friendly communication, but also gives a brief overview of the word "salam" and its meaning through the Qur'an, in order to learn, from the basic source of Islam, what the true peace is, how it is achieved and what are the meanings of an Islamic salutation.

At the beginning, the word "peace" is defined in Bosnian and Arabic. After that, words from the Qur'an that contain the root "s $l m^{\prime \prime}$ are quoted, and the word "salam" is underlined. Paper represents a kind of journey through Qur'anic verses - it stops at each word "salam" to see in what context it is used and what message theat treasury of found verses carries for us. Ibn Kesir's tafsir was used to briefly explain these verses. The personal review of the author, including its own understanding of the mentioned verses and offering their interpretation. Regarding the word "salam" in the hadiths of the Prophet, peace be upon him, in the paper it is stated several guidelines on this topic from Tirmidhi's collection of hadiths.

Key words: Salam, peace, The Qur'an, ayat, badith 
السيدة المعيدة نينا خليلباشيتش جامعة بيهاتش كلية التربية الإسلامية nina-halilbasic@hotmail.com

\section{السلام - كلمة السلام}

\section{الخلاصة}

يتحدث هذا البحث عن أهمية التحية كأولى الخطوات في التواصل الاجتماعي، من أجل خلق إنقا

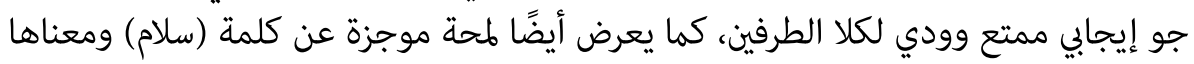

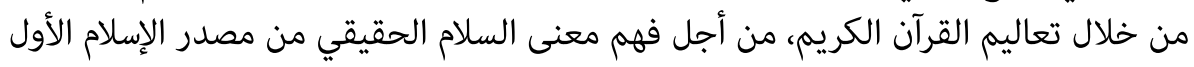

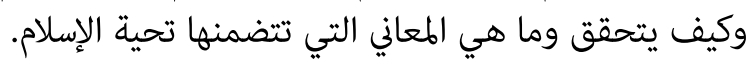

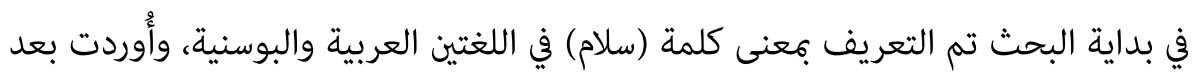

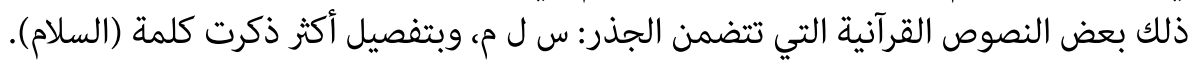

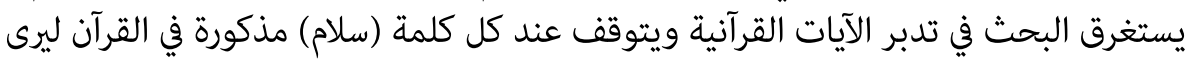

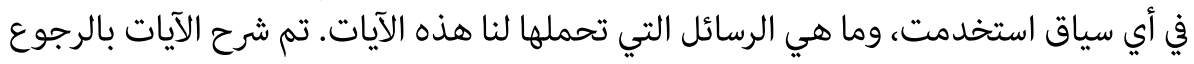
إلى تفسير ابن كثير، كما تم إيراد ترجمة له، وذئ إنكر فهمه للآيات وتفسيرها.

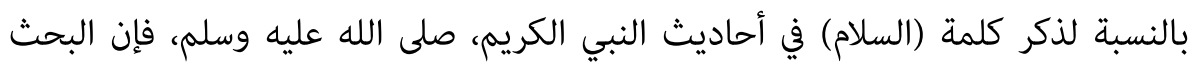

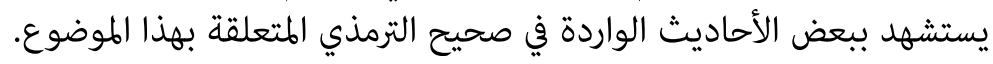
الكلمات المفتاحية: سلام، السلام، القرآن، آيات، حديث. 